\title{
Stigmatization (Health Coverage)
}

\section{AUTHOR}

Doreen Reifegerste, Annemarie Wiedicke

\section{KEYWORDS}

framing, stigmatization, mental health, media coverage

\section{BRIEF DESCRIPTION}

Media descriptions of mental illness and the mentally ill are often characterized by stigmatization. For example, in media coverage mental illnesses are often associated with crimes and violence (Ma, 2017). In consequence, patients are presented not only as peculiar and different, but also as dangerous. Thus, the media maintain misconceptions and stigma (Klin \& Lemish, 2008; Srivastava et al., 2018).

\section{FIELD OF APPLICATION}

Health communication, anti-stigma communication, anti-stigma research, stigmatization

\section{EXAMPLE STUDIES}

Carpiniello et al. (2007); McGinty et al. (2014)

\section{INFORMATION ON CARPINIELLO ET AL. 2007}

Authors: Bernardo Carpiniello, Roberta Girau, Maria Germana Orrù

Research questions: The study explores the portrayal of mental illness in Italy's leading national and regional newspapers, asking whether a different pattern emerged in describing criminal offences committed by the mentally ill in reports relating to homicides, suicide, and other acts of violence.

Object of analysis: The total sample included $\mathrm{N}=$ 2279 all articles relating to homocides, suicides or attempted suicides as well as acts of violence in two leading Italian newspapers (Corriere della
Sera, $\mathrm{n}=387$ and La Repubblica, $\mathrm{n}=375$ ) and the two leading regional newspapers (L'Unione Sarda, $\mathrm{n}=783$ and La Nuova Sardegna, $\mathrm{n}=733$ )

Time frame of analysis: October 2002 to March 2003

\section{INFO ABOUT VARIABLES}

Variables: For each article it was coded whether or not the criminal offence had been attributed to a mentally ill person (actions were deemed to have been attributed to the mentally ill only when clearly stated or strongly alluded to by the author of the article) as well as use of stigmatizing language (Penrose-Wall et al., 1999)

Reliability: No information

Level of analysis: News article

Topics

- Homicide

- Suicide

- Attempted suicide

- Homicide + suicide

- Sex-related violence

- Other violent acts

Attribution to a mentally ill person

- yes

- no

Stigmatizing language

- Fool/foolishness

- Monster/monstrosity

- Maniac/maniacality

- $\mathrm{Mad} / \mathrm{madness}$

- Insane/ insanity

- Lunatic 


\section{REFERENCES}

Carpiniello, B., Girau, R., \& Orrù, M. G. (2007). Mass-media, violence and mental illness. Evidence from some Italian newspapers. Epidemiologia E Psichiatria Sociale, 16(3), 251-255. https://doi.org/10.1017/s1121189x00002359

Klin, A., \& Lemish, D. (2008). Mental disorders stigma in the media: Review of studies on production, content, and influences. Journal of Health Communication, 13(5), 434-449. https://doi.org/10.1080/10810730802198813

Ma, Z. (2017). How the media cover mental illnesses: a review. Health Education, 117(1), 90-109. https://doi. org/10.1108/HE-01-2016-0004

McGinty, E. E., Webster, D. W., Jarlenski, M., \& Barry, C. L. (2014). News media framing of serious mental illness and gun violence in the United States, 1997-2012. American Journal of Public Health, 104(3), 406-413. https://doi.org/10.2105/AJPH.2013.301557

Penrose-Wall, J., Baume, P., \& Martin, G. (1999). Achieving the balance: A resource kit for Australian media professionals for the reporting and portrayal of suicide and mental illnesses. Publications Production Unit (Public Affairs, Parliamentary and Access Branch), Commonwealth Dept. of Health and Aged Care.

Srivastava, K., Chaudhury, S., Bhat, P. S., \& Mujawar, S. (2018). Media and mental health. Industrial Psychiatry Journal, 27(1), 1-5. https://doi.org/10.4103/ipj.ipj_73_18 